CZASOPISMO INŻYNIERII LĄDOWEJ, ŚRODOWISKA I ARCHITEKTURY JOURNAL OF CIVIL ENGINEERING, ENVIRONMENT AND ARCHITECTURE

JCEEA, t. XXXIV, z. 64 (3/I/17), lipiec-wrzesień 2017, s. 407-416, DOI: 10.7862/rb.2017.133

\author{
Zbigniew KOWAL ${ }^{1}$ \\ Monika SIEDLECKA ${ }^{2}$
}

\title{
NOŚNOŚĆ BLISKOGAŁĘZIOWYCH PRĘTÓW ŚCISKANYCH W STRUKTURACH PRZESTRZENNYCH
}

\begin{abstract}
Analizie poddano bliskogałęziowe pręty ściskane o długościach modułowych rzędu a $=3 \mathrm{~m}$, stosowane $\mathrm{w}$ ściskanych pasach piramidowo-bocznych systemów montażowych regularnych struktur przestrzennych np. systemu ,Zachód”. W takich prętach bliskogałęziowych, traktowanych jako pręty zwarte, stosowano cztery połączenia śrubowe w odstępach znacznie przekraczających wytyczne aktualnej normy europejskiej wynoszące $15 i_{\min }$. Brak doniesień o awariach z tego tytułu stał się przyczyną badań modelowych. W badaniach modelowych zauważono, że między śrubowymi połączeniami w prętach dwugałęziowych występuje zjawisko samoczynnego wewnętrznego sprężenia gałęzi zwiększające ich nośność krytyczną w obszarze sprężystej utraty stateczności. Sposób wykorzystania tego zjawiska do zwiększenia nośności prętów bliskogałęziowych pokazano na przykładowych schematach. Sprężanie od wewnątrz prętów bliźniaczych może być stosowane w celu zwiększania nośności istniejących konstrukcji oraz $\mathrm{w}$ przypadku projektowania nowych konstrukcji zawierających pręty bliźniacze. W związku z tym, że opisywane zjawisko można wykorzystać w wielu różnych przypadkach, stanowi ono przedmiot dalszych badań piramidowo-bocznego systemu montażowego.
\end{abstract}

Słowa kluczowe: pręt złożony, pręty bliźniacze, przekrycie strukturalne, sprężenie od wewnątrz, sprężenie samoczynne, piramidowo-boczny system montażu

\section{Wprowadzenie}

W pracy pokazano możliwości wykorzystania zjawiska wewnętrznego sprężenia prętów bliskogałęziowych do zwiększenia nośności, zwłaszcza ściskanych prętów bliskogałęziowych stosowanych np. w strukturach przestrzennych.

Poszukując rozwiązania konstrukcyjnego [1] celem podwyższenia nośności ściskanych prętów pasa górnego struktur przestrzennych autorzy niniejszego referatu opracowali zgłoszenie patentowe pt. Konstrukcja pręta wielogatęziowego. Przedmiotem wynalazku jest wewnętrznie sprężony pręt wielogałęziowy.

\footnotetext{
${ }^{1}$ Zbigniew Kowal, Politechnika Świętokrzyska, al. Tysiąclecia PP 7, tel. 413424596, z.kowal@tu.kielce.pl

${ }^{2}$ Autor do korespondencji / corresponding author: Monika Siedlecka, Politechnika Świętokrzyska, al. Tysiąclecia PP 7, tel. 413424802, monikach@tu.kielce.pl
} 


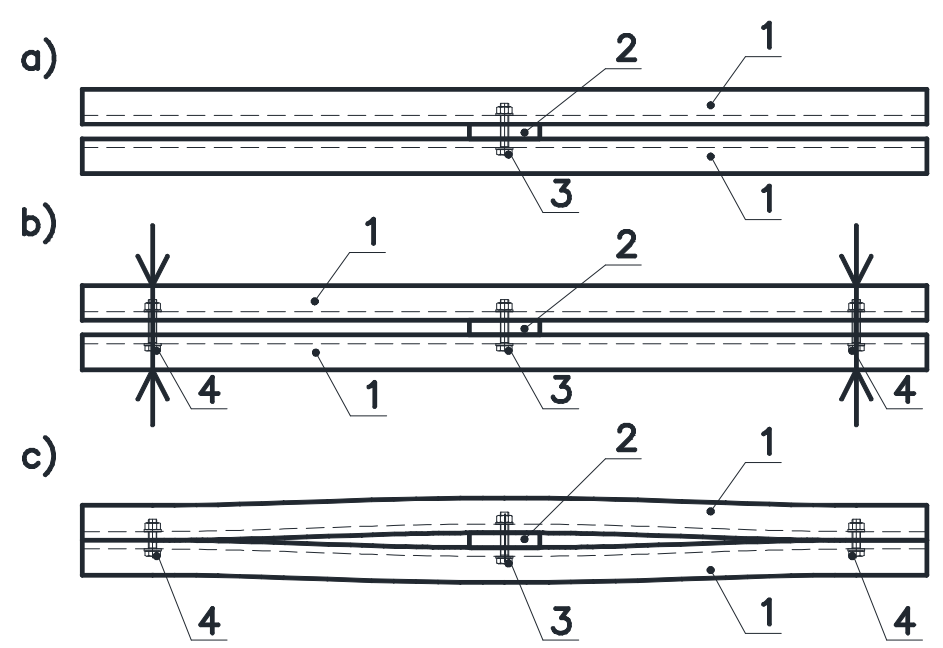

Rys. 1. Proces sprężania ściskanych prętów bliskogałęziowych; a) faza A, b) faza B, c) wewnętrznie sprężony pręt bliskogałęziowy;

1 - gałąź pręta bliskogałęziowego, 2 - element dystansowy, 3 - łącznik elementu dystansowego, 4 - śruba sprężająca

Fig. 1. Process of prestressing in closely spaced built-up members; a) phase A, b) phase B, c) closely spaced built-up member prestressed from inside 1 - chord of closely spaced built-up member, 2 - spacer, 3 - connector of the spacer, 4 - pre-tension bolt

Proces sprężania od wewnątrz podzielono na dwie części A i B.

W fazie A (rys. 1a) w środku długości pręta wprowadzono element dystansowy w postaci blachy 2 przymocowanej śrubą 3 .

W fazie B (rys. 1b) w dwu przekrojach połączono ze sobą gałęzie pręta za pomocą śrub sprężających 4.

W efekcie otrzymano pręt bliskogałęziowy o prostoliniowej osi i nieliniowym przebiegu gałęzi wg rys. 1c.

Sprężenie wprowadzane jest $\mathrm{w}$ bliskogałęziowych prętach ściskanych zagrożonych międzywęzłową utratą stateczności w przekroju, w którym w wyniku sprężystego wyboczenia pręta, zgodnego z pierwszą postacią wyboczenia, potencjalnie wystąpiłyby największe przemieszczenia między węzłami (rys. 6a lub 6b).

Wprowadzone do gałęzi naprężenie wstępne $\sigma_{0}<f_{y}$ nie powinny przekraczać minimalnej granicy plastyczności $\boldsymbol{f}_{\boldsymbol{y}}$. Na rys. 2 . przedstawiono przykładowy rozkład naprężeń wstępnych $\sigma_{0} \mathrm{w}$ przekroju z elementem dystansowym. 

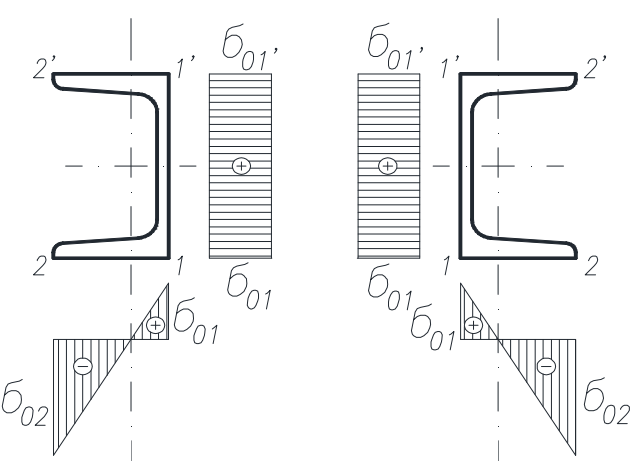

Rys. 2. Naprężenia wstępne $\sigma_{0} \mathrm{w}$ przekroju sprężonego pręta bliskogałęziowegoz elementem dystansowym

Fig. 2. Initial stresses $\sigma_{0}$ in the cross-section of prestressed closely spaced built-up member with a spacer

Na rys. 3. pokazano przykładowe schematy sprężonych od wewnątrz prętów bliskogałęziowych.
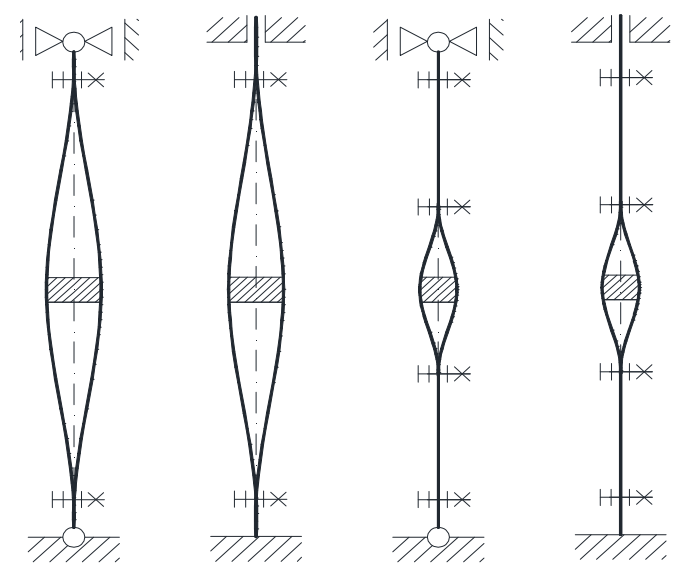

Rys. 3. Przykładowe schematy sprężonych prętów bliskogałęziowych

Fig. 3. Exemplary diagrams of prestressed closely spaced built-up members

\section{Stan wiedzy na temat wymiarowania ściskanych elementów bliskogałęziowych}

Według normy europejskiej [2] ściskane pręty bliskogałęziowe należy wymiarować analogicznie do elementów złożonych o pasach równoległych według p. 6.4. Elementy złożone ściskane zaleca się projektować $\mathrm{z}$ uwzględnieniem wstępnej imperfekcji - jako mimośrodowo ściskane w ujęciu teorii II rzędu. Wstępne wygięcie $e_{o}$ występujące w postaci jawnej, dla pręta przegubowo pod- 
partego, przyjęto w normie [2] równe $L / 500$, gdzie $L$ stanowi długość teoretyczną elementu.

Zgodnie z normą [2], projektowanie prętów złożonych, połączonych przylgowo lub rozsuniętych na grubość blachy węzłowej można przeprowadzić jak dla pręta jednolitego, gdy rozstaw osiowy między złączami nie przekracza $15 i_{\text {min }}\left(i_{\text {min }}\right.$ - minimalny promień bezwładności jednej gałęzi).

Wymiarowanie ściskanych prętów bliskogałęziowych według polskiej normy [3] jest tożsame z wymiarowaniem ściskanych elementów wielogałęziowych. Elementy złożone traktuje się jako ściskane osiowo, a imperfekcje, uwzględnione w sposób niejawny, ukryte są w smukłości zastępczej $\lambda_{m}$ oraz współczynniku wyboczeniowym $\varphi$.

Zgodnie z polską normą [3] oraz literaturą [4, 5] dwugałęziowe pręty, których gałęzie rozsunięto na grubość blachy węzłowej lub nieco więcej zaleca się liczyć jako pręty zwarte pod warunkiem, że szczelina między gałęziami jest wypełniona przekładką lub zastosowano w zamian nity przekładkowe w odstępach nie większych niż $15 i_{\text {min }}$. Ponadto elementy złączone bezpośrednio ze sobą przez nitowanie, zgrzewanie lub spawanie wg [3] powinno traktować się jak jeden pręt.

\section{Zastosowanie elementów bliskogałęziowych w przekryciach strukturalnych}

Analizę szeroko stosowanych prętów bliskogałęziowych w regularnych przekryciach strukturalnych przeprowadzono na przykładzie systemu „Zachód” [6], zaprojektowanego w piramidowo-bocznym systemie montażowym (rys. 4.) o module $\mathrm{a}=3 \mathrm{~m}$. Pręty łączone są ze sobą przylgowo wzdłuż boków podstaw wg rys. 4-5. Pasy warstwy górnej przekrycia stanowią więc symetryczne pręty bliskogałęziowe.

$\mathrm{W}$ rozpowszechnionym $\mathrm{w}$ świecie piramidowo-bocznym systemie montażowym struktur przestrzennych, stosowanych zwłaszcza w przekryciach hal o średnich i dużych rozpiętościach według schematu pokazanego na rys. 4-5, stosowano 4 łączniki w prętach bliskogałęziowych pasów ściskanych. Pręty te projektowano jako pręty zwarte. $\mathrm{Z}$ tej przyczyny nie odnotowano dotąd awarii czy katastrof przekryć, co wskazywałoby na poprawność przyjętych wówczas rozwiązań.

Stosowane odległości między łącznikami wynosiły od $\sim 29$ do $\sim 50 i_{\min }$ dla par kątowników i do $\sim 75 i_{\text {min }}$ dla par ceowników C80E. 

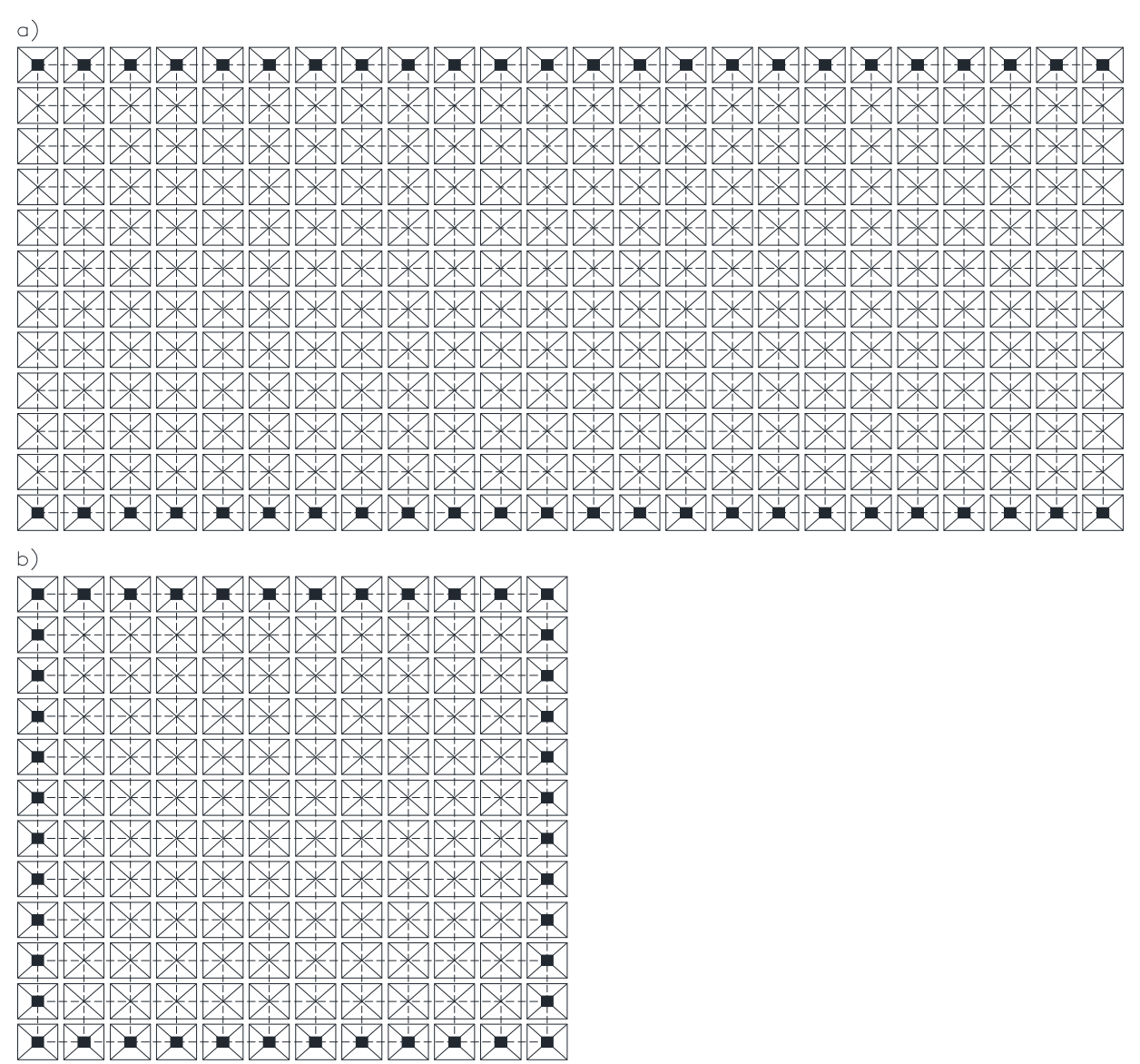

Rys. 4. Schemat rozmieszczenia piramid przekrycia strukturalnego podpartego a) wzdłuż dłuższych boków hali, b) na obwodzie

Fig. 4. Diagram of the pyramid location in structural cover supported a) along the longer sides of the hall, b) along all the sides of the hall

W niniejszym artykule analizie nośności poddano ściskane pręty bliźniacze o przekrojach bisymetrycznych.

W strukturach można wyróżnić dwa skrajne przypadki wyboczenia prętów w strefie górnej w piramidowo-bocznym systemie montażowym: 1) w długich halach, kiedy przekrycie podparte jest wzdłuż dłuższych boków (rys. 4a i 6a); 2) w przekryciach o rzucie kwadratowym lub prostokątnym o proporcjach boków zbliżonych do jedności, z podparciem na obwodzie (rys. 4b i 6b). 


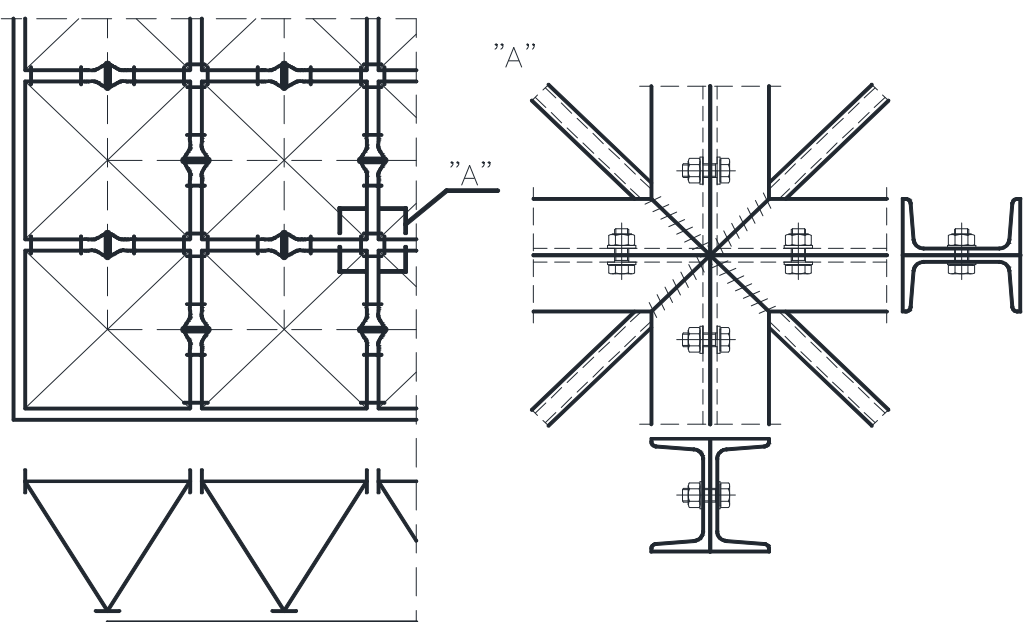

Rys. 5. Przykładowe połączenie prętów ściskanych w węzłach górnego pasa struktur w piramidowo-bocznym wariancie montażowym

Fig. 5. Exemplary of connection of compressed bars in the nodes of the upper chord of the structures in the pyramidal-lateral assembly system
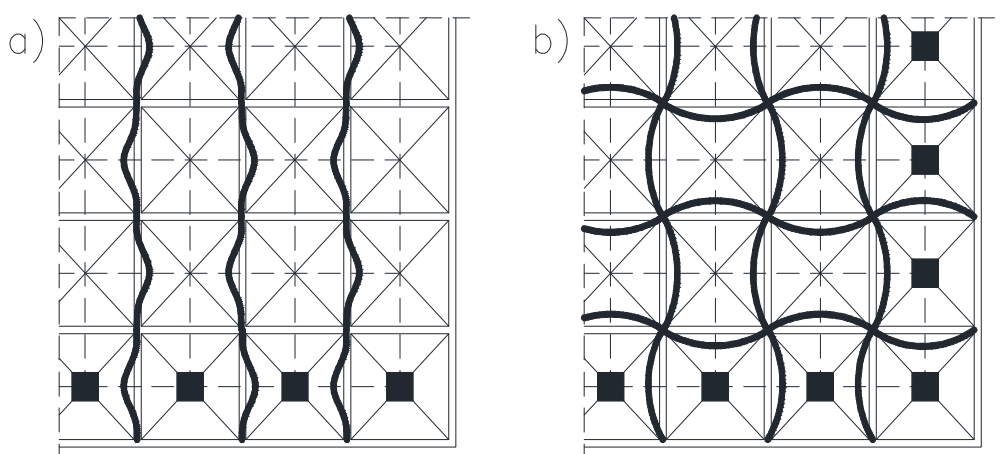

Rys. 6. Utrata stateczności pasa górnego struktury podpartej a) wzdłuż dłuższych boków hali, b) na obwodzie

Fig. 6. Stability loss in the upper chord of structural cover supported a) along the longer sides of the hall $b$ ) along all the sides of the hall

\section{Badania modelowe}

W celu wyjaśnienia przyczyn niezawodnej pracy prętów bliźniaczych w zrealizowanych strukturach o piramidowo-bocznym systemie montażowym przeprowadzono szereg eksperymentów. Do badań wybrano przypadek wyboczenia pokazany na rys. $6 \mathrm{~b}$ - pręt pasa przegubowo podparty w węzłach, o najmniejszej nośności krytycznej. 
Dla porównania rozwiązań badaniom modelowym poddano również pręty bliskogałęziowe wg rys. $7 \mathrm{a}$.

W dwu próbach osiowej sile ściskającej poddano modele prętów bliskogałęziowych (rys. 7a) podpartych obustronnie przegubowo. Modele prętów zbudowano z dwóch płaskowników aluminiowych ułożonych przylgowo o przekroju 2x20 [mm], długości 1,0 m połączonych śrubami M4 co $30 \mathrm{~cm}$. Elementy uległy wyboczeniu globalnemu, po obciążeniu siłą odpowiednio $71,99 \mathrm{~N}$ i $70,52 \mathrm{~N}$.

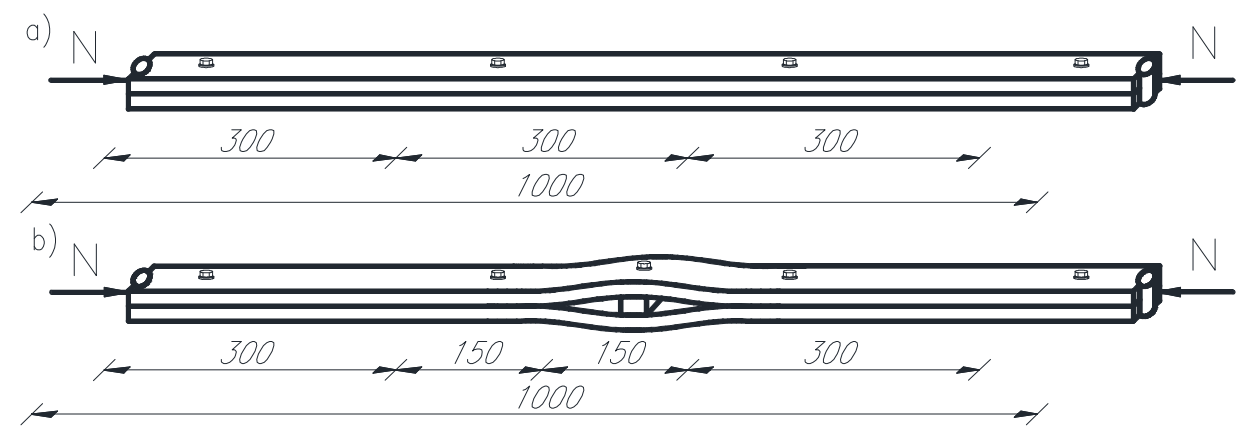

Rys. 7. a) Klasyczny pręt bliskogałęziowy, b) pręt bliskogałęziowy sprężony od wewnątrz i przytrzymany śrubą

Fig. 7. a) Conventional closely spaced built-up member, b) closely spaced built-up member prestressed from the inside and held by bolt

Również w dwu próbach osiowej sile ściskającej poddano modele sprężonych od wewnątrz prętów bliskogałęziowych (rys. 7b) podpartych obustronnie przegubowo. Modele zbudowano z ułożonych przylgowo dwóch płaskowników aluminiowych o przekroju 2x20 [mm], długości 1,0 m połączonych śrubami M4 co $30 \mathrm{~cm}$, sprężonych od wewnątrz w środku rozpiętości przekładką dystansową o grubości $4 \mathrm{~mm}$. Pręty zablokowano śrubą przed dalszym powiększaniem przemieszczeń poprzecznych. Pręty uległy wyboczeniu globalnemu, po obciążeniu siłą odpowiednio 99,40N i 98,42N.

Moduł Younga, dla płaskowników ze stopu aluminium, stanowiący wartość średnią, wyniósł $\mathrm{E}=68465 \mathrm{MPa}$.

Zwiększenie nośności krytycznej wstępnie sprężonego pręta bliskogałęziowego w stosunku do pręta o przekroju zwartym wyniosło ok. 27,9\%.

Trzeba jednak zaznaczyć, że do badań wykorzystano pręty bliskogałęziowe o dużej smukłości.

Z badań wynikło, że sprężenie od wewnątrz prętów bliskogałęziowych daje największe efekty w obszarze sprężystej pracy prętów wstępnie sprężonych. 


\section{Rozkład naprężeń w sprężonych prętach bliźniaczych}

W ściskanym bliskogałęziowym pręcie sprężonym, podpartym obustronnie przegubowo lub utwierdzonym, pokazanym na rys. 1. i 3., najbardziej wytężony jest przekrój w połowie rozpiętości elementu.

Ze względu na symetrię układu w rozważaniach wzięto pod uwagę jedną z gałęzi elementu. Pręt bliskogałęziowy poddany jest działaniu następujących obciążeń: 1) sprężenie w wyniku wstępnego wygięcia gałęzi, 2) ściskająca siła osiowa $N, 3$ ) moment zginający $\boldsymbol{M}(N)$ jako efekt działania siły ściskającej $N$ na mimośrodzie.

Według powyższej technologii wykonania występuje superpozycja (1) naprężeń pokazana na rys. 8 .

$$
\sigma=\sigma_{0}+\sigma_{\mathrm{N}}+\sigma_{\mathrm{M}(\mathrm{N})}
$$

gdzie: $\sigma_{0}$ - naprężenie wstępne; $\sigma_{N}$ - naprężenie od osiowej siły $\mathrm{N}$ ściskającej element; $\sigma_{M(N)}$ - naprężenie od zginania siłą $\mathrm{N}$ na mimośrodzie.

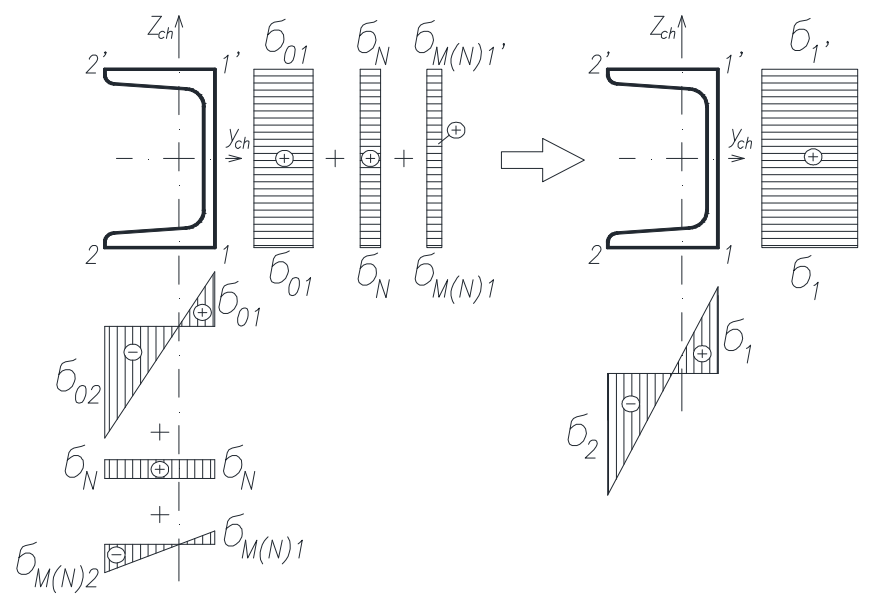

Rys. 8. Rozkład naprężeń w najbardziej wytężonym przekroju jednej gałęzi ściskanego pręta bliskogałęziowego sprężonego od wewnątrz

Fig. 8. Stress distribution in the most stressed cross-section of one chord in compressed closely spaced built-up member prestressed from the inside

Oszacowane naprężenie $\sigma_{N} \mathrm{w}$ jednej gałęzi od osiowej siły $\mathrm{N}$ ściskającej element bliskogałęziowy można zapisać znaną zależnością (2):

$$
\sigma_{\mathrm{N}}=\frac{0,5 \cdot \mathrm{N}}{\mathrm{A}_{\mathrm{ch}}}=\frac{\mathrm{N}}{2 \cdot \mathrm{A}_{\mathrm{ch}}}
$$

gdzie: $N$ - siła osiowa ściskająca pręt złożony; $A_{c h}$ - pole przekroju jednej gałęzi pręta złożonego. 
Naprężenie $\sigma_{M(N)}$ od zginania gałęzi pręta bliskogałęziowego siłą N na mimośrodzie oszacowano zależnością (3):

$$
\sigma_{\mathrm{M}(\mathrm{N})}=\frac{\mathrm{M}(\mathrm{N})}{\mathrm{W}}=\frac{\mathrm{N} \cdot \mathrm{y}_{\mathrm{N}}}{\mathrm{W}_{\mathrm{z}, \mathrm{ch}}}=\frac{\mathrm{N} \cdot \mathrm{y}_{\mathrm{N}} \cdot \mathrm{y}}{\mathrm{J}_{\mathrm{z}, \mathrm{ch}}}
$$

gdzie: $N$ - siła osiowa ściskająca pręt złożony; $y_{N}$ - współrzędna $y$ punktu przyłożenia siły ściskającej $N$ względem osi głównych przekroju pojedynczej gałęzi; $W_{z, c h}$ - wskaźnik wytrzymałości względem osi $z$ jednej gałęzi pręta złożonego; $J_{z, c h}$ - moment bezwładności przekroju względem osi $z$ jednej gałęzi pręta złożonego; $y$ - odległość od osi przekroju pojedynczej gałęzi do punktu, w którym wyznaczane są naprężenia.

\section{Uwagi, wnioski i zalecenia}

Brak awarii bliźniaczych prętów ściskanych w piramidowo-bocznych systemach montażowych struktur przestrzennych można wyjaśnić swobodą przemieszczeń na zewnątrz od osi wg rys. $7 \mathrm{~b}$. Swoboda przemieszczeń wpływa na zmniejszenie energii wyboczenia, zwłaszcza w środku rozpiętości prętów bliźniaczych, w których oczekuje się największych przemieszczeń.

Z uwagi na nieefektywne rozwiązania, do których może prowadzić aktualna norma [2] w zakresie wymiarowania prętów bliskogałęziowych z łącznikami rozmieszczonymi rzadziej niż co $15 i_{\min }$, zjawisko sprężenia od wewnątrz może być szeroko wykorzystane w rozwiązaniach konstrukcyjnych.

Zjawisko wewnętrznego sprężenia wpływające na zwiększenie nośności ściskanych elementów konstrukcji złożonych można celowo wykorzystać w budowie i optymalizacji oraz wzmacnianiu wielu konstrukcji, zwłaszcza struktur przestrzennych.

Przedmiotem dalszych badań jest oszacowanie nośności krytycznej ściskanego pręta bliskogałęziowego sprężonego od wewnątrz.

\section{Literatura}

[1] Kowal Z.: Stateczność słupa dwuodcinkowego o przekroju dwuteowym. II Sesja Wydziału Budownictwa Lądowego PWr., Wrocław PWN 1963, Referaty t. I., s. 143-155.

[2] PN-EN 1993-1-1 Eurokod 3. Projektowanie konstrukcji stalowych. Część 1-1: Reguły ogólne i reguły dla budynków.

[3] PN-90/B-03200 Konstrukcje stalowe. Obliczenia statyczne i projektowanie.

[4] Jankowiak W.: Konstrukcje metalowe. PWN, Warszawa - Poznań 1983.

[5] Szlęzak F.: Budownictwo żelbetowe i metalowe. Cz. II Budownictwo metalowe. PWN, Warszawa 1987.

[6] Kowal Z., Polak M., Szpila E., Wydra S.: System przekryć przestrzennych „Zachód”. Inżynieria i Budownictwo, 1976, nr 11, s. 421-424. 


\section{LOAD BEARING CAPACITY OF COMPRESSED CLOSELY SPACED BUILT-UP BARS IN SPACE STRUCTURES}

\section{S u m m a r y}

The paper presents analysis of closely spaced built-up bars under compression. The bars, the module length of $\mathrm{a}=3 \mathrm{~m}$, are used in compressed chords of pyramidal-lateral assembly systems of regular space structures. In such built-up bars, treated as one bar, four bolted connections were employed. The distance between the connections significantly exceeded the one recommended by the current Eurocode 3 which is $15 i_{\min }$. Failures related to the solution above were not reported, which became a stimulus for conducting research on models. It was observed in the investigations that in two-chord bars between bolted connections, spontaneous internal prestressing between the chords occurred. That enhances the member ultimate bearing capacity in the zone of elastic stability loss. The effect can be achieved due to spontaneous prestressing from inside of twin bars. The application of the phenomenon to the enhancement of the bearing capacity of closely spaced built-up bars was demonstrated with the use of exemplary diagrams. Prestressing from inside can be applied to the existing structures in order to increase the ultimate bearing capacity, or to the design of new structures that contain twin bars. As the phenomenon described in the study can be used in many different cases, the issue needs to be included in further research onpyramidal-lateral assemblysystem.

Keywords: built-up bar, twin bars, space structure cover, prestressing from inside, spontaneous prestressing, piramidal-lateral assembly system

Przestano do redakcji: 24.05 .2017 r.

Przyjęto do druku: 01.09.2017 r. 